\title{
Chapter 8 \\ Transforming Adult Education from \\ Neo-liberal to Holistically Inclusive Adult \\ Education in Baltic States
}

\author{
Kai Pata, Irina Maslo, and Larissa Jõgi
}

\section{Introduction}

In this chapter, we explore the data of nation-wide adult education programmes in three Baltic states. These programmes incorporate informal learning elements from the perspective of active participatory citizenship (APC) and, therefore, this provision aims to enhance opportunities for young adults in vulnerable positions. We posit that the concept of active participatory citizenship (EduMAP Concept Note 2017) that aims at developing young adults' politico-legal, socio-cultural and socio-economic proactiveness could be used for illustrating these educational programmes from the holistic education aspects (Jarvis and Parker 2005). Holistic approach to adult education (AE) denotes that knowledge is a multi-faceted social construct which intertwines explicit, implicit and emancipatory (transformative) learning. Individual, social and organizational learning activities can unify persons' conceptual, perceptual and affectual knowledge facets for personally meaningful learning (Yang 2003, 2006). According to Biesta (2015) education has multidimensional purpose: qualifying individuals with necessary knowledge, skills and dispositions, socializing them into social, cultural and political practices, and enhancing their own initiative and responsibility.

As the starting point, the chapter gives an overview of the historical trends in adult education in the Baltic states, and the interpretation of the concept of lifelong learning and adult education. Next, it opens up the two case studies conducted in

\author{
K. Pata $(\bowtie)$ \\ School of Digital Technologies, Tallinn University, Tallinn, Estonia \\ e-mail: kpata@tlu.ee \\ I. Maslo \\ University of Latvia, Riga, Latvia \\ L. Jõgi \\ School of Educational Sciences, Tallinn University, Tallinn, Estonia
}


Estonia and Latvia during the Horizon 2020 project EduMap fieldwork undertaken in 2018. The chapter describes two national adult education practices that target all age groups, but we narrow our analysis down to highlight how these programmes promote learning for and learning through active participatory citizenship (APC) among young adults from vulnerable groups. Since the programmes have not been designed merely to aid the vulnerable adults, we posit that focusing on how the needs of this target group have been addressed, might highlight the general gaps of the programmes to offer holistic adult education for all. In both practices, we explore how different dimensions of APC are manifested in legal acts, programme documents, and among different stakeholders' (policy-makers, adult educators and the young adults) viewpoints about the programme provision. The interviews with policy-makers, adult educators and the young adults from risk groups have been used to identify the holistic adult education approaches and the gaps in supporting young adults to become active participating citizens.

\section{Historical Trends in Adult Education in Baltic Countries}

The Soviet period in the Baltic states (1940-1992) was characterised by socialist humanistic educational goals. Soviet people were considered a "nation of students", emphasizing everyone's freedom to learn and access to learning but also thereby purposefully shaping the socialist attitudes, the acquisition of interests, and the formation of convictions for developing the intrinsically motivated need and values to be educated for taking responsibilities in the Soviet society (Ross 1960). Education followed the principles of Soviet patriotism, the communist attitude towards work as a matter of honor, fame and heroism. Other significant principles included collectivism, socialist humanism and consciousness based on the foundations of Marxism-Leninism, materialist world view, and military training (Kera 1996: 31-32). To promote social justice and cohesion various forms of adult education were provided free of charge, through evening schools for adults, correspondence courses, Palaces of Culture, People's universities, as well as at workplaces through so-called evening tuition circles, and at Sunday universities. Yet, encouraging learning for vocations was the main approach, and, as a result there were constraints in personal choices, which contributed to in the intellectual and cultural values of education and learning being somewhat undermined.

Despite historical and regional closeness, the three Baltic states have undergone different adult education (AE) development paths after regaining their independence. Each country's system of lifelong learning and adult education has been the result of specific national developments and traditions, but there have also been strong international trends and influences. Since the 1990s, the role and possibilities of adult education and professional training for adults have been growing rapidly in all three states. In the sections below we take a brief look at the trends in adult education in Estonia, Latvia and Lithuania during the last two decades (2000-2019). 
After regaining independence and entering the market economy, the Baltic states as well as other European Union countries went through the neo-liberal changes resulting in adult education taking the main direction in mobilizing people for continuous learning and transforming learning into a desirable consumer commodity (Saar et al. 2013). The Baltic states have been members of the European Union since 2004, which contributed to a more stable social, cultural, political and economic environment. In the post-soviet period (1991-2007) the discursive space for adults in the Baltic states has decreased enormously with regard to learning for other reasons than labour market competitiveness (Saar et al. 2013). In the neoliberal discussion on active citizenship, the importance of employment and effective economic and societal participation, and citizens' entrepreneurial attitudes have been stressed and encouraged beyond the personal development goals in learning (Brooks and Holford 2009: 11-12). The next sections will consider some emerging trends in adult education and lifelong learning in Estonia, Latvia and Lithuania, over the past 20 years.

\section{Estonian Republic}

During last 20 years, the process of economic, political, social-cultural and technological changes had a major impact on the developmental trends of adult education practices and legislation in Estonia. The main changes in the Estonian society that can be looked upon as challenges to adult education and lifelong learning policy are the following: transformation to market economy, transition to democratic society, maintenance of national identity and moving towards an information society. The period 2000-2019 was characterised by several trends in the development of adult education. The implementation of new legislation has contributed to reshaping both the content of training and structure of educational institutions, as well as, stimulated further changes in the organisation of education system. In addition, different forms of international co-operation were growing and the role of non-governmental organisations has increased significantly (Jõgi 2005). Formal educational system has been more and more relying on adults' self-development, and there is an economic pressure on individuals to continue their learning. Learning and training opportunities for adults have been promoted through formal, non-formal and informal levels of adult education (Aava 2009; Country Report 2011; Helemäe et al. 2000; Jõgi and Märja 2000; Estonian Human Development Report 2001; Lifelong Learning Needs Analysis 2001; Saar et al. 2013). Workplace learning, work-related courses and vocational training for adults, as well as participation in lifelong learning have increased during the last 10 years reaching to $20 \%$ of the population. Estonia is ahead of the European average when it comes to the number of both women and men participating in life-long learning (Adults participation in learning 2019). There is a strong focus on the development of digital competences of adult learners (Education and Training Monitor 2018). The resources from the European 
Social Fund have significantly improved the education opportunities for adult learners.

In the context of Estonian labour market and population trends, the need for upskilling and reskilling has been considered particularly important (MoER 2015). A human capital model, where lifelong learning connotes continuous work-related training and skill development to meet the needs of the economy and employers for a qualified, flexible and adaptable workforce, still dominates in Estonia (Aava 2009). The greatest expectation in society is related to both the economic development and growth, and therefore the significance of personal success and education is not widely seen as relevant to it (Jõgi et al. 2007).

The person-centred advancements in the forms of adult education and lifelong learning during the socialist period were partially reversed in the beginning of postsocialist era (Saar et al. 2013) when workplaces became the major drivers of adult learning (Roosalu and Roosmaa 2010). At the same time, paradoxically, some surveys (Ernst and Young 2017) have shown that 38\% of those who participated in the courses were not satisfied with workplace-based learning opportunities and $22 \%$ were not satisfied with their study programmes. As a recent trend in adult education in Estonia, adult participation in learning continues to increase, however, the need for reskilling and upskilling is high especially among young adults. The group of young adults (15-29) not in education, employment or training (NEET) comprises $12.5 \%$ of this age group (2015). The importance of non-formal and informal learning as a means of social inclusion of young adults from vulnerable groups into active life was also emphasized in the Estonian Youth Work Development Plan for 2014-2020, adopted at the end of 2013. The latest two trends in Estonian adult education are related to both the growing educational opportunities for adults and growing focus on the quality of training providers in nonformal learning in connection with workplace innovation, re-skilling and up-skilling of people (ET 2020). While vocational competences are mainly provided through training programmes, youth organisations, youth centres and hobby schools provide opportunities for acquiring social and digital competences (ET 2020).

\section{Latvian Republic}

The paradigm of pedagogy in Latvia started to change in the 1990s, involving transition from the authoritarian action towards human collaboration, in which the transformation of the best practice patterns developing self-experience with new knowledge, skills and attitudes were highlighted (Spona 2018:18). This stemmed from the cultural-historical learning principles developed by Lev Vygotsky in the 1930ies. In Latvian post-soviet era, from 2003 to 2007 AE served as a foundation of lifelong learning (Koķe 1999). It functioned with well established and mostly publicly (by state and municipalities) funded regional adult education centres, evening 
schools for second chance education, Folks High schools, etc. all over the country. Following the economic crisis in 2008, the public funding breakdown has resulted in the closing of AE centres, evening schools, Folk High-schools (Kārkliņa and Papule 2017), and opening of evening classes at the premises of mainstream schools. Currently Latvia is again moving towards "education for adults" (instead of "adult education"), considering that "formal, non-formal and informal learning of adults" would provide benefits to learners themselves, employers and the wider community (EC 2016). There are some opportunities for young vulnerable adults including onthe-job training, second chance education, validation of informal education and informal competences (Procedure for the Validation of the Professional Competence Acquired Outside Formal Education System, Republic of Latvia, Cabinet Regulation No. 146. adopted 22 February 2011).

\section{Lithuanian Republic}

In Lithuania AE has been a secondary concern of education system reformers in the post-Soviet era, as they tended to give more prominence to "mainstream" education while underestimating the importance of both access to higher education for adult learners, and lifelong learning goals. Education has been first and foremost viewed as an important vehicle for the nation-building and fostering economic and political stability. Through reviewing Lithuanian education strategy and reforms, it has emerged that at recent years Lithuania has been making active efforts in the entire education system in the direction of lifelong learning (Taljunaite et al. 2010). The interests of the state, employers and individuals focus on adequate qualifications to compete in the labour market (Dromantiene and Źemaitaityte 2014). One of the purposes of National Qualifications Framework of Lithuania (2007) is to facilitate the recognition of various forms of learning and to encourage lifelong learning. In relation to informal training, there exist the legal preconditions for the recognition of informally acquired competences (The Law on Non-Formal and Continuing Education accepted on the first January 2015), but the practices of assessment and recognition of these competences are only in the piloting stage and are not widespread.

The Baltic states are currently in the neo-liberal state of educational provision, targeting mainly socio-economic aspects, however there are some trends to facilitate informal modes of learning and training. In particular, Latvia and Lithuania have made steps to promote informal forms of education for gaining socio-economic competences, and are generally directed towards holistic forms of offering adult education. 


\section{Lifelong Learning Concept and Strategies in Adult Education Policies}

The greatest influence on adult education policy in the Baltic states has come from European Union Lifelong Learning and Adult Education policies. Adult education policy in the Baltic states has been designed according to the education development guidelines set by the following European educational policy documents: Lisbon Strategy, Bologna Process, European Commission Memorandum on Lifelong Learning, UNESCO program Education for All, and European Commission work programme Education and Training 2010. Its use continued after discussion of the Memorandum on Lifelong Learning, Making a European Area of Lifelong Learning a reality, drafted and adopted by the European Council and Lisbon European Union Conclusions, in which it is pointed out that lifelong learning is an important precondition for a successful transition to a knowledge based economy and society (Jõgi and Gross 2009). The concept of lifelong learning (LLL) came into active use in educational policy after 1996. The purpose of lifelong learning in educational policy documents was economic policy dependent and highly job-related (Aspin et al. 2012: 7).

Baltic National Acts and programmes have largely adopted the European concepts of lifelong learning, however, the development differs in how these countries have operationalized the LLL concept, for instance in the legislation and the educational policy documents. According to Holford et al. (2007) the LLL concept in European Union educational policy has become constrained by its vocational orientation, having the needs of the economy and employers in mind. Our desk research has indicated both similarities and differences in the national conceptions and interpretations of LLL in the Baltic States.

The Estonian Lifelong Learning National Strategy 2020 (LLL 2020) determines LLL narrowly and instrumentally, in relation to the skills, knowledge and job competencies from the labour market perspective. The main trends in $\mathrm{AE}$ include on-the-job training as a form of vocational training, flexible transfer between study levels, bringing young adults not in education, employment or training (NEET) to education and work, and social cohesion programs (LLL 2020). However, according to Estonian LLL 2020 the following principles are significant in developing lifelong learning, i.e. learner's active participation and responsibility; cooperation and learning from each other; the quality, flexibility, transparency and trustworthiness of learning opportunities; gender equality; prosperity of the Estonian state, its language and culture as well as sustainable development (LLL 2020: 4). Despite the strong focus of digital competency and incorporation of digital culture into the learning process (LLL 2020: 14) the agendas lack the attention to the holistic view of LLL and non-formal and informal education in LLL discourse. The holistic selfdirected educational development for own transformation, and the emancipatory development in collectivist and social contexts are underestimated compared with socio-economic related development goals. Learning at work contexts is supported with some work-embedded vocational practices, but the validation of the 
competences from non-formal and informal education for obtaining formal qualifications has not become a mainstream practice.

In Latvia, the notion of LLL for AE is based on the concept of "adult education" for continuing personal and professional development rather than on the concept of "education for adults" in civil society targeted on adult learners' benefits. The latter concept is the future objective of Latvian adult education in its national agenda. Several opportunities for young vulnerable adults exist, but active changes are taking place in the context of on-the-job training, second chance education, and validation of non-formally obtained competences. The most prominent trend in the Lithuanian LLL concept in AE, sets goals through the concept of "education for adults", that is targeting building social capital, supporting people in advancing themselves and their personality through LLL to contribute to society, and fostering social cohesion. Several laws and programs focusing at informal learning have created the basis for accrediting informally obtained competences. In state policies, in Lithuania, informal education is seen as the tool for aiding vulnerable adults. In comparison, Estonia, Latvia and Lithuania have already taken some legislative steps to fortify adult education and LLL goals and means, thus moving beyond training adults primarily for employment and labour market.

\section{Active Citizenship Concept in Adult Education}

"Learning for active citizenship" was stated as one of three major pillars in LLL (Commission of the European Communities 2000). Active participatory citizenship (Kalekin-Fishman et al. 2007; EduMAP Concept Note 2017) has the following dimensions (see also Chap. 1):

Socio-cultural dimension sets informal education into a particular role in learning for inclusive citizenship. It is about exercising tolerance and democracy in interaction between individual people's voluntary activities and self-development, and public sector activities.

Politico-legal dimension aims at channeling persons' political agency so that democratic practices would be 'owned' by citizens. It is not just voting (responsive citizenship) but becoming engaged in policy-making (active citizenship) so that the specific socio-political order can be democratically reproduced.

Socio-economic dimension is about making individuals less dependent upon the state, mobilizing them for transforming learning into a desirable consumer commodity. It targets thin government services and active citizens' services (e.g. social enterprises) and entrepreneurship.

Young persons themselves have voiced active citizenship through their universal status as a sense of membership or belonging to the community, as a respectable economic independence, as a constructive social participation taking the constructive stance towards the community, as social-contractual relation with the community related with persons' rights and responsibilities, and as their right to have a 
voice (Lister et al. 2003). These are aspects that may contribute to overcoming vulnerability and exclusion of young adults from the everyday life, and should be addressed in the attempts for providing holistic education inclusively.

Learning for active citizenship is seen as part of LLL in which a person constructs the crucial links between learning and societal action linking formal and informal learning, individual and collective actions and making dynamic connections between citizenship as status and citizenship as practice. Learning through citizenship is learning active citizenship mainly by practicing it in various areas of social life: civil society, work, and what is usually designed as the private sphere (Kalekin-Fishman et al. 2007).

In the remaining sections of the chapter we are using active participatory citizenship (APC) concept dimensions as a lens in two case studies of adult education practices collected during the EduMap project (2018) in Latvia and Estonia. We are looking at how learning through active citizenship is achieved at providing adult education for vulnerable young adults, and whether learning for active citizenship has taken place. We aim to discuss whether and how the cases indicate towards holistically inclusive approaches in Baltic states' adult education.

Overall, based on our analysis of educational acts in Baltic states, active citizenship concept has been operationalized in educational acts largely through the focus on developing citizens' entrepreneurial attitudes and individuals' abilities to be less dependent upon the state. There is a clear direction indicating less reliance on the government-provided services and complementing those by active citizens' services (e.g. social enterprises) and entrepreneurship.

\section{Estonian Republic}

In Estonian legal acts (Legal documents database: http://riigiteataja.ee) the concept of active citizenship in Government acts is rare and it is prevailingly not defined. The focus lies in the citizen's capability and willingness to have a positive impact in the society (socio-economic dimension). The active citizenship concept appears in multidimensionally defined way in national curricula. Neo-liberal views can be seen in the ways the national curricula treat citizenship at both basic and secondary levels. The concept of 'active and responsible citizen' is used in the Curriculum for basic schools (Art. 11), in which it is named as one of the democratic competences to be achieved (politico-legal dimension), and the Curriculum for secondary level (Art. 5) highlights 'civic initiative and entrepreneurship', aiming at students to become active and responsible members of the society (socio-economic dimension). In High school acts and specific universities' acts, active citizenship is defined through the ability to demonstrate individual initiative (socio-economic dimension). The Adult Education and Hobby Education Acts do not define active citizenship concept. Estonian Lifelong Learning Strategy (2020) defines active citizenship indirectly through the key competences. Estonian Social Acts use the concept of participation in social life (socio-cultural dimension). The Citizenship Act defines new 
citizens by coping in society and through language competences (socio-cultural dimension). We may conclude that the approach in Estonia is separating the active participatory citizenship dimensions between educational, civic and social domains.

\section{Latvian Republic}

In the Latvian legal documents the citizenship concept is not directly defined. Generally, the Educational law highlights the development of independent and developed personality, conscientious and responsible member of democratic society, participating in social and public life (socio-cultural dimension). The concepts of active citizenship is at present in the roadmap for Sustainable development 2030 document in the democratic activism in decision-making context (politico-legal dimension). In Latvia the concept of 'active and responsible citizen' plays an important role in the policy document of Sustainable Development Strategy of Latvia until 2030, which claims that "[E]veryone will have the opportunity to feel safe and belonging to Latvia, everyone [here] will have the opportunity to achieve his or her goals" (socio-cultural dimension). Apart from seeking to achieve their own goals, active citizens are important actors for the ambition of Latvia to 'become the leader of Europe in the introduction of innovative government mechanisms' (politico-legal dimension).

\section{Lithuanian Republic}

The Lithuanian previous Law of education emphasized the development of individuality, humanistic values, democracy, sense of civic duty to family, society and nation (socio-cultural dimension), and participation in social, economic (socioeconomic dimension) and political life (politico-legal dimension). The new version of the legislation has included a number of changes. In particular, it emphasizes that the citizens ought to be independent, responsible and patriotically-minded (sociocultural dimension) and develop several related competence areas; the citizens ought to develop professional qualifications for labour market, they ought to support sustainable development of the country (socio-economic dimension), preserving cultural identity but also creating openness (socio-cultural dimension). In addition, there are expectations of an individual to be a competent citizen of the Republic of Lithuania, a member of the European and global community, as well as, of a multicultural society (socio-cultural dimension). Lithuanian Strategy 2030 has a special focus on happy society that is open to the ideas of each citizen, enabling everyone to pursue their favorite activities. It highlights social responsibility which contributes to the national success, openness to different views, responsibility for actions taken, morality, active concern not only for themselves, but also the environment, community and the country at large (socio-cultural dimension). The substance of 
citizenship is mainly discussed in the Lithuanian Progress Strategy 'Lithuania 2030'. The concept of 'active citizen' is not explicitly used in this document, but citizens are described as proactive, enterprising, trusting their fellow-citizens, (socio-cultural dimension) creative in their solutions and ready to take risks (socioeconomic dimension). Ideally, citizens would assume responsibility not only for themselves but also for the others and for the society, with a strong feeling of national ownership (socio-cultural dimension). The image of the citizen as an active and responsible actor, demonstrating 'growing civic maturity' (politico-legal dimension) is connected with the ideology claiming that the government must reduce areas of intervention, thus enabling citizens and communities to take responsibility into their hands (Lietuva 2030: 10,25). The Lithuanian Progress Strategy is a pure example of a neo-liberal view of the society. Active citizens are needed, because of the desire to diminish the role of the state in favour of private entrepreneurship.

Considering the three countries' approaches to define the concept of active citizenship, we can conclude, that in comparison with Estonian legal acts, the future agendas in Latvia and Lithuania already consider broader active citizenship concepts.

\section{Informal Education Cases for Young Adults from Vulnerable Backgrounds}

Changes towards recognizing holistically inclusive adult education have brought attention to the significance of informal learning in the context of adult education in the Baltic States. Informal learning is also seen as a means of supporting young adults from vulnerable groups in becoming active citizens. Below we introduce two case studies from the EduMap project representing good practice cases of informal education in Estonia and Latvia. The cases were selected on the basis of their potential in supporting the active participatory citizenship (socio-economic dimension) of young adults specifically through employing the informal and work-embedded educational practices. Both cases were nationwide educational practices in the vocational education in 2018. As in Estonia and Latvia, there is a large percentage of Russian speaking population. The programmes aim to encourage this target group to engage with the programme and take courses either in Estonian and Latvian languages. In addition, in some vocational institutions the programme is also offered in Russian. In both cases, we interviewed individually the policymakers (11) associated with the programme development, adult educators (10) who teach in these programmes and the young adults (16) who had taken part in the programme. The data were coded using the Edumap coding framework, where the active participatory citizenship dimensions were among the categories.

The case in Estonia describes the broadly practiced approach of vocational workembedded learning as the form of adult education. The case in Latvia describes the 
case of validating at formal educational institutions the competences obtained at work context and in informal education.

\section{Estonian Case - Vocational Work-Embedded Education}

\section{Description of the Programme}

The work-embedded vocational education ${ }^{1}$ and adult education provision programme in Vocational Education Institutions (VET) in Estonia is provided nationalwide by different vocational schools jointly with workplaces. The programme targets young adults with lower levels of education, and offers more suitable and flexible study forms, giving professional qualification to people at workplaces, and it can also introduce young adults to their first jobs. The programme is tailored to the priority goals related to preparing competent staff to the job market and promoting entrepreneurship. This vision mainly supports socio-economic dimension of APC. The programme is based on vocational competence standards and ends with qualification exam. The vocational schools, enterprises through the Employers Association (https://www.employers.ee) and the Estonian Ministry of Education and Research make the three-sided contract for offering certain curricula at workembedded mode. The successful vocational institutions organise studies among several enterprises, which provide different type of practice. The agreement guarantees training by enterprise mentors, the enterprises will get payed for mentoring. Fourty percent of the places are planned for young adults without basic education or qualification. The student is engaged with the three-sided study contract where enterprise is part of. The whole programme is curated from the school side. The mentors receive special training, their activities are orchestrated by the mentors' coordinator at school who keeps track of all the students. The students are mediated both by the vocational school, as well as, by the workplace mentors. Studies are largely conducted under the guidance of mentors at workplaces during actual work practice, additionally, a week in a month or a day in a week is held at vocational schools with the VET educators. The enterprise mentors have to grade competence development of learners - often the provision of vocational exam is divided into step by step smaller graded tasks - so people do not need to do the big exam and extensive studies for it. The digital- or paper-based portfolios are used for reporting the learners' success. The studies are module-based - usually there is a career planning module, economy and entrepreneurship module (socio-economic dimesnion) among others. The studies are blended with digital materials accessible usually in Moodle environment, but rather the face-to-face mode is preferred, and Moodle is used (not in all vocational institutes) to maintain portfolio approach of reporting of the progress of learning competences at workplaces. In many cases, learners use paper-based

\footnotetext{
${ }^{1}$ https://www.innove.ee/haridusprojektid/prom/
} 
practice diaries instead, where students must reflect on their own progression and development. Learning at a vocational institute is group-based, the particular learning needs of language minorities are considered such as providing Russian language worksheets, providing additional help - the learners are usually with the basic education, also students with specific educational needs may be taken in to some of work-embedded programmes (such as gardening, hotel work etc.). For vulnerable young adults, it is critical that the mentor and the curator introduce them to the workplace, and are further monitoring if the student is sufficiently self-directed. Some young adults (students coming from special simplified learning programmes) attend workplace learning under the guidance of personal assistants.

The programme provides various supportive means for students. The students under 21 may get free school lunch support, but it was not described in the programme documents how they can get it while at workplaces. Additional financial support (stipend) of 60 euros is provided for higher achieving students, and about 60 percent of students receive this scholarship. The students are also provided with additional language lessons if needed.

Central training programmes for coordinators in vocational schools are arranged. At vocational institutions there are some practical trainings for educators to handle the vulnerable target groups - mainly how to cope with special education needs, and language minorities. The entrepreneurship training programme for educators is on the way. Training for workplace mentors is the VET obligation, usually they train how to fill in the feedback in student diaries, and how to assess competences - main focus is creating harmony in learning outcomes and practices how to teach at workplaces. Tandem training for workplace mentors and VET mentors is on the way offered by Estonian Ministry of Education and Research.

In summary, this national work-embedded AE program in VETs develops practices and distributes different practice models for job embedded vocational training. The practice based learning at work helps young adults from vulnerable backgrounds to know how certain practices must be applied, they get salary while studying, they should receive job and have better understanding of what they want to do in their life. The tailored mentorship helps to improve their self-organization competences. The learning peers become friends and widen the social arena of young adults. The joint activities at VETs tie young adults better to seeing what way society functions.

\section{Target Group}

The programme is targeting wide learner groups (addressing the requirement of inclusion of all learners), but does not specifically address vulnerable young people. We have observed that in the actual implementation of the programme, vulnerable jobless young people do not gain access as easily as was envisaged by the programme policy goal. It is challenging for young adults to navigate through digitally 
provided VET web-pages and through information portal for vocational education, created by the ministry. The major challenge is to decide what fits to their particular needs in adult education provision, and discover additional social services which are usually provided by the Social Minisitry and may be found in their information web-pages or from Estonian X-road of services. The specific adult education programmes offering work-embedded tuition, and their benefit to vulnerable youth, are not so visible at the VET's webpages and on the leaflets of VETs distributed in key areas where young people may receive advice and guidance. There are some means that support young adults from vulnerable backgrounds to access AE. The extra social services (travel support, some scholarship support, rules that support getting salary while studying) and the mentor services (for being embedded to learning and working habits) are provided to address specific discrepancies. Critical gaps exist in how vulnerable young adults are handed over from one mentorship and adviser to another in different educational levels.

\section{The Active Participatory Citizenship Concept in Programme Application}

Policymakers' APC Conceptions The policymakers from the Estonian Ministry of Education and Research, vocational education section, were familiar with the APC concept from some strategy documents, but they could not relate it with the concrete agendas of the observed case of on-job vocational training. The policymakers described the compulsory learning modules in vocational curricula related with entrepreneurship as active citizenship training (socio-economic dimension). They noted APC as an active engagement, involvement to community and policymaking, and as a quality of being knowlegeable and aware of the issues in society, not being outcasted (politico-legal dimension). APC was related with the person who fulfils her/his citizen duties (politico-legal dimension). It was also related with economic success of the country through increasing employment (socio-economic dimension).

APC in the Work-Embedded VET Programmes From the interviews with the policy-makers we found that in the Estonian case of work-embedded vocational education the active citizenship concept was considered in preparing programmes but not as the explicitly defined, central and clearly addressed goal. The educators in VETs informed us that at vocational adult education programme level (curricula) the socio-political (knowing regulations, normatives in the field discipline) and socio-economic dimensions (how to get job, how to be actively self-employed, few entrepreneurship courses) were more addressed than socio-cultural (this part was left to workplace mentors and was not educationally supported). The socio-cultural dimension was not addressed by courses. 
Adult Educators' APC Conceptions Adult educators had vague conceptions about APC, and they did not see it related with their workplace learning programmes concretely. APC was related to citizen initiative (Politico-legal dimension); the right to receive lifelong education (Socio-cultural dimension), but it was considered just broadly relevant in AE context. Rather it was considered in the context of the wider perspective for human development in general (Socio-cultural dimension). It was also described as an outcome of being trained. Adult educators considered the following socio-cultural barriers to AE and APC: Young persons' age was considered as a restriction to take part in work-embedded AE - young adults with vulnerable background were described as not having self-discipline and ability to plan own life. Lack of self-responsibility was seen as a barrier to AE and indirectly to APC. It was considered critical to have a transmission-mentor for helping the young adults when they are in between different educational and work opportunities (falling out from vocational education) and to provide mentoring for working and self regulation habits both at the AE side as well as at the work-embedded AE situations. Educators pointed to the gap in linking the young vulnerable adults with Unemployment office, and expected that there should be a two-way transition path that the young adults in Unemployment office could find the programme opportunities and employment.

Young Adults' APC Conceptions The APC conception was not clear to some respondents and they had not been thinking of it, and even asked from the interviewer the meaning of it. Some young people related all their life to being a citizen. APC was related with:

Socio-economic dimension: Living and working in the country; contributing to the country such as with taxes, and being an honest taxpayer; paying taxes was also seen as an obligation, a contribution and a commodity to receive other commodities from the country, such as safety and help.

Socio-cultural dimension: APC was also associated with other rights such as health insurance and right for learning; having the aims and aspirations; being respectful to his parents and family.

Politico-legal dimension: It was associated with not being passive, showing interest to the government; providing feedback and ideas to the regional government; participating in elections.

\section{Programme Outcomes for Young Adults from Vulnerable Groups}

Young adults claimed that they learned practical competences, and they now know what working means in reality. They had experienced real-life job interviews. They felt they became more independent because they got salary, but the backside was 
that students who had not received work were still living dependent on parents (socio-economic dimension).

They saw better where they might fit with their competences and had better future aspirations - they felt like finding themselves. They learned to assess themselves, and became more self-organized, self-confident and valued themselves more as part of the society. The students with special educational needs felt more confident in life, but still relied heavily on the help of their personal assistants in coping with taxes, contacts etc. They learned how to communicate better, but still felt not confident in communicating with foreigners (some were not open to communicating with immigrants and other nationalities). Language skills remained an issue for some students. The students appreciated they became better involved in the society, having field trips with the VET. They had made more friends (socio-cultural dimension). They did not see that they should participate in civil and political life, since their voice was not considered (politico-legal dimension).

\section{Challenges of the Programme}

We conclude that the provision of work-embedded vocational education for young adults with vulnerable backgrounds in Estonia should be better organized and orchestrated between different institutions of employers, employers' associations, unemployment offices and VETs in order to ensure the open vacant practice places for the programme applicants who are unemployed.

The programme must become more flexible, regarding the size of study groups and different job-embedded professional opportunities. People need to have a chance to study what interests them; however, this is impossible because they usually live in others' care unable to move to study in other regions because they are financially and socially dependent.

The learners reported learning a lot as a result of engaging in this adult education initiative, and getting aspirations from work-embedded learning (socio-cultural dimension). On the other hand, they did not always become independent and find job after graduating - perhaps society should also think of in-service trainings and get-together follow-ups for young adults to keep them engaged in lifelong learning. Secondly, employing all people according to their capabilities, and providing them support and specific services in becoming independent from parents is important. The programme should further develop socio-cultural and politico-legal dimensions of APC, to ensure activism and tolerance in the society, not tailoring only the job-related goals. Self-development is equally important in the age of digitalization to face multifarious changes during the life course. 


\section{Critical Elements for Young Adults to Become Active Citizens}

Our data suggest that the practice-based learning at work helped young adults from vulnerable groups to understand how certain practices might be applied. What is more, the learners receive salary while both studying, and working (socio-economic dimension), and, therefore, they develop better understanding of their future career choices and what they want to do in their life. The tailored mentorship helped them to improve their self-organization competences. The joint activities with their peers in the context of VET, provided opportunities for teamwork and social communication, thus enabling young adults to understand better the way society functions (socio-cultural dimension). Generally, there was the need to increase the selfesteem, aspirations, communication and self-organization competences of young adults from vulnerable backgrounds at work-embedded vocational education - the teachers needed to learn how to facilitate the development of general competences in the work embedded mode. The AE educators should also promote civic-juridical competence development in the programme to prompt activism of young adults in local life (politico-legal dimension).

The main barriers to APC were seen by young adults as follows:

Socio-economic aspects: Being unemployed and not finding a job. Being unconfident in presenting oneself. Not ready to live independent life, paying taxes, renting the apartment, making contracts. Not financially coping alone in the society, and having dependency of parents who support them.

Socio-cultural aspects: The Adult education being too much knowledge focused instead of practices. Fear of communicating and particularly the fear of different people who do not master local language. Lack of knowing foreign languages.

Civic-political aspects: The young adults from vulnerable background were sure that their voice will not be considered, if they want to be active at a regional government level.

It may be concluded that Estonian case of work-embedded vocational education in VETs could target both the socio-economic and socio-cultural dimensions of the active participatory citizens' competences among vulnerable groups of young adults. Yet, while adult educators recognized supporting particularly the sociocultural aspects, these were not well embedded in the programme. The policy documents and interviews with policy-makers revealed mostly the socio-economic dimension of APC lacking holistic orientation. 


\section{Latvian Case - Validation of Informal Learning}

\section{Description of the Programme}

The case of competence validation of informal and non-formal vocational education $^{2}$ in Latvia demonstrates an alternative way to become qualified for low-skilled young adults: they can identify competence gap, get additional studies tailored to their needs, and finally they can take the competence validation test. The approach assumes that the professional competencies acquired in non-formal education may also be formed by knowledge, skills and abilities gained through personal life and job experience. The State on Education Quality Service is responsible for the delegation of competence validation right - the application requirements for competence validation and the methodology are provided by the responsible institution. Organisations that typically run validation of informal vocational education competences are vocational education institutions, competence and examination centres all over Latvia. ${ }^{3}$ All formal vocational education programmes (up to education level - 03) are governed by Education Law and Vocational Law, and other regulatory acts and licenced by the State Education Quality Service. Educational institutions are entitled to provide non-formal adult educational programmes without obtaining a licence, but other legal persons, which are not registered in Educational Institution Register, need a licence from the local government. "Lifelong Learning Policy Guidelines 2007-2013 state that "formal, non-formal and recognition, validation and accreditation of adult informal learning ${ }^{4}$ are equally important and supplement each other in the lifelong learning policy, thus enriching the learning culture, experience and widening the educational environment on the level of an individual, community and society at whole" (holistic approach) (Kārkliņa et al. 2017: 86).

Competence validation of informal and non-formal vocational education (up to competences level 03) is available for unlimited range of professions. The evaluation of professional competencies mastered outside the formal education is based on a test of the corresponding professional standard at the professional qualification examination.

Institutions that carry out public adult education policies go to villages to contact young adults and find out their educational needs for APC and after that, they prepare the education policies. There is an availability of a career counselling for all, independent from their societal status (socio-economic dimension). The most successful approach is the availability of the counselling in open libraries, where young

\footnotetext{
${ }^{2}$ https://ikvd.gov.lv/arpus-formala-izglitiba/

${ }^{3}$ https://ikvd.gov.lv/arpus-formala-izglitiba/profesionalas-kompetences-novertesana/

${ }^{4} \mathrm{LR}$ CM, Rules for recognition of competences acquired outside formal education or acquired in professional experience and recognition of learning outcomes achieved in previous education, LR MF regulations No. 505, Riga, August 14, 2018 (prot. No. 38, section 12) ensure the recognition, validation and accreditation of adult informal learning at all educational levels.
} 
adults of vulnerable groups receive advice, support and can receive information of this AE programme.

Learners can get a profession within 1-1,5 years throughout validation of informal learning and/or at the end of the training, complete the 15-week qualifying practice with broad mobility opportunities and take the qualification exam. Competent inter-institutional collaboration is providing them timely support by the need. Young adults have the opportunity to get work-experience while learning, at the same time receiving salary and social benefits. During the qualification practice of 15 weeks students are accompanied by an employer who will need their newly acquired skills, they are payed for travel and accommodation costs up to $€ 71$ per month, payed the civil liability insurance provided with compulsory medical examinations needed for the specifics of the chosen profession. They receive a scholarship from 70 to 115 euros per month, transport/Internet subsidies, and free accommodation during the studies. Childcare services for AE participation are available (socioeconomic dimension).

Workplace learning is organized mostly by employers at workplaces in cooperation with vocational institution and/or colleges. Work-related subject teaching is done by employer in the workplace to ensure that learners would acquire the useful knowledge and skills for social, cultural, economic and civil life in work-situations. The students can obtain the certificate necessary for the profession, for example, work with a cash register, work with a system for booking tourist services, a car or tractor driving license, etc. The certificates are provided for in the specifics of the chosen profession (socio-economic and socio-cultural and politico-legal dimensions).

Learning approach is personalized and individualized: Young adults can access mentors/tutors outside of lessons for not only academically issues, but also for dialogical informal communication/discussions and experiences about social, cultural, economic and civil life exchanges (socio-economic and socio-cultural and politicolegal dimensions).

Self-directed learning is promoted through the opportunity to combine studies and work: the organized learning activities are free of charge, providing flexible opportunities to choose the learning time and place. Young adults have the opportunity to access the mentors outside of formal learning activities, online materials, and interactive e-learning opportunities. AE provider has to deliver community learning opportunities in special education, in non-formal education, and in formal adult education to facilitate the sense of community in all types of education and workplace learning through collaboration and communication with peers and in teams (socio-cultural dimension). Educational services are provided in nontraditional way by involving young adults into group and community activities to help them see possibilities beyond the limited environment. Individual dimension is important to design for a number of competency complexes to upgrade the result and support the person who is responsible for creating socially significant values (socio-cultural dimension).

E-Learning is the key element of this good practice. Information server is provided where all the learning materials are available, as well as, the materials from 
the previous years; learners can see all the materials of courses at their own place and pace and may even attend educational activities online. The number of adult learners in groups is small and the individual approach to each learner is taken. Access to the adult educator is provided who may send students e-mail, or call them, and just tell when they are available.

\section{Target Group}

The programme targets low-educated and low-skilled adults with low motivation, misunderstanding of learning benefits, who often do not have information about educational programs implemented by an educational institution and the modern vocational education system as a whole - they are not students who are enrolled in an educational institution and have completed vocational education programs, have not been in contact with the educational environment and educators. They are not officially defined as vulnerable groups in legislation, they have no organizational structure or own meeting places. They often have problems how to maintain their life, they are disorientated in life and work situations, and have low self-esteem. The programme targets gender needs by communicating of professions gender neutral ways, it has some tailored means for language minorities, low educated students and students with special education needs.

\section{The Active Participatory Citizenship Concept in Programme Application}

Active participatory citizenship is described by stakeholders and by programme as follows:

Policymakers' APC conceptions particulary address APC related with persons' responsibilities and alignment to the nationally stated approaches: "We use the term 'active civic participation' and we are interested for better understanding how this concept/term is defined and used in other organizations as well", "Being an active citizen ... in my opinion is to be a citizen who (a) nevertheless thinks about the country and about education in our horizons; b) takes responsibility for our actions; and c) correct to the principles of disparity, cooperates with the public administration in the particular case. If there is a problem, s/he is very correct and concrete to deal with it" (politico-legal dimension).

Adult Educators' APC conceptions also address the conformity requirement of educators as active citizens, but additionally value in decision-makers the personal will and freedom: "Being an active citizen means not being indifferent to issues of general interest and without fear of expressing one's position. I believe that in public 
administration, employees have restrictions on being personally civic activists, because they have to comply with decisions taken by the government" (politicolegal dimension).

There is not much evidence that the programmes directly contributed to and cultivated APC. In fact, that is because the APC was not mentioned in the country's normative regulations.

Young adults' APC conceptions focused rather on themselves, and other persons they interact with in their everyday life and job situations:

Socio-cultural Dimension Friendships are considered important and are associated with social cohesion aspect of APC: "It is important to keep in touch with friends who have kept the church despite the time and geographic location", "Make new friends", "Create new relationships participated in sport-teams, dance collectives, choirs, song festivals, music-bands, amateur collectives or by fishing etc.", "The process of friendship is natural, and only the satisfaction of the social needs is important".

Communication skills and particularly the increased confidence in communicating is highlighted as an active citizen competence: "Confidence in communication", "Good Latvian and English language skills, good verbal communication skills".

Raised self-esteem is noted as one of the important aspects that increases active citizenship: "Definitely raised self-esteem through the improved knowledge baggage", "More self-confidence and faith in what one is doing", "Confidence in the desire to work in the chosen profession".

Tolerance to diversity as an APC component indicates the young adults' awareness for more cohesive society: "We do not share common traditions or work", "Experience exchange between the people from diverse cultures. Breaking stereotypes that someone of a different nationality would want to hurt you.", "Intercultural communication in diverse working/job situations", "Communication experience with many other religions from all over the world".

Raised interests to informal self-development was mentioned as a personal APC characteristic: "Increased reading interest".

Increased scope of informally learnt experiences also associated with APC: "Life-experiences abroad (mobility experiences)".

Socio-economic dimension of explaining APC particulary highlighted the employment and practical experiences view.

Finding job: "Finding qualified job related to own abilities, interest carrier opportunities and good salary or/and opening own business", "Using acquired knowledge and skills to find information in competent information survey".

Wider practical experiences: "Widespread practical experience", "More opportunities instead of those at current workplaces", "Using the acquired knowledge and skills in practical work at workplaces and in family life." 
Politico-legal dimension was the only APC dimension were young adults associated themselves with the citizen responsibilities and contributing to their country.

Political responsibility was noted as APC: "I vote".

Active concern was another dimension young adults addressed related with APC concept: "Thinking about what happens in own country, in the area of taxes and legislation, when and why something goes wrong and what happens, thinking about all kind of things that happen in birth- or life place and doing the very best for your own country."

\section{The Outcomes of the Programme for Vulnerable Young Adults}

The learners have highlighted the following testimonials as outcomes of learning in the programme:

Socio-economic dimension addresses mainly person's increased opportunities to have job and salary for their families.

"To live and work with the family."

"To have enough money to love own children and wife so that the family does not feel neglected."

"To become competent for a good sustainable job with good salary for having a family."

"To manage financial things to be able to continue their education."

"To receive the career opportunity and access to continued education, and to do something for people and country."

"To acquire the professionally useful knowledge."

"To be competent in their profession."

"To compose their CV."

"To assure a next profession."

However, some learning outcomes are related with open and active forms of learning that increase the opportunities:

"To participate in international professional courses.".

"To participate in projects."

"To create a new computer programme in the professional branch."

Socio-cultural dimension highlights the importance of formal education certificates and lifelong learning for young adults.

"To pass the qualification exam."

"To continue studies in Higher education with state financing."

"To get more opportunities in life."

"To get higher education."

"To put some things to the end, not leave unfinished halfway."

Young adults also consider informal ways of learning from other people, such as in travelling important.

"To travel, to meet a lot of people."

Politico-legal dimension mainly highlights the outcomes that relate with the person's ability to conform with the state:

"To orient in the changing legislation." 


\section{Programme Challenges}

The needs of the adult learners from vulnerable groups are hard to be identified in the national documents about Latvian Lifelong learning guidelines. Accessibility and motivation issues remain critical. Preventively, the conditions should be clarified that allow groups at risk to participate in the social, cultural, economic and civil life. Adults with low basic skills often do not recognize the need for education and are not motivated to become involved. Educational documents do not show clearly defined educational needs in the adult target groups, and the need for active participative citizenship. It is difficult to access the groups, defined as the groups at risk.

The AE local coordinators funding depends on projects. There has been a discrepancy between national regional and local policies in practice. Municipalities are not provided with the sustainable funding for $\mathrm{AE}$ and adult learners at risk. Opportunity to get a qualification is provided but it does not offer further education opportunities for young adults from risk groups. Ensuring sustainable workplaces/ job during the $\mathrm{AE}$ is a challenge. Merely the job related professional competences are validated as learning outcomes in the programme, but not the general competences such as communication, self-directedness etc. The young adults perceive that programmes are not relevant, they find that $20-40 \%$ of the educational content is interesting, but $60-80 \%$ of the content is boring and there are few connections with social, cultural, economic and civil life. Studies that are conducted mostly in the e-environment exclude the young adults from direct contact with the instructor and the course-mates, which discourages communication skills development in real-life situations. The young adults with families and job find the requirement to attend compulsory classes (to avoid missing lessons and losing their scholarship) difficult.

\section{Programme Outcomes and Challenges for Young Adults}

The learning outcomes related with the socio-economic dimension were the most addressed ones at the programme courses. The course alumni reported that the programme did not always increase their intrinsic interest to work on the studied job. The programme was successful in promoting their openness to be self-employed. However, they perceived that the programme did not address sufficiently specific entrepreneurship competences, such as, how to find funding for doing own business.

The learning outcomes related with the socio-cultural dimension were mainly learnt at informal occasions. The alumni reported multicultural tolerance towards the people they interact with. The young adults with vulnerability background percieved problems related to inclusion. For example, their digital competences were not sufficient to benefit from digitally provided services, and they felt left aside.

Some learning outcomes of politico-legal dimension were embedded in the programme. Young adults reported of learning about normatives in specific vocational domains. However, they criticized that real life normatives often constrain 
vulnerable people who cannot economically follow the normatives. Despite of programme studies they felt knowing weakly their rights and opportunities. They reported that they became more active as responsible citizens participating in voting, and being active in work unions. They admitted willingness to impact policymaking, but complained that there are constraints that hinder them. Particularly they found that some national laws are made to constrain democracy, demonstration and participation which inhibits exercising the policies that they would like to support.

Latvian case of validating informal competences and training for the accreditation exams may be summarized as follows. In the policy documents and among the policymakers the APC concepts were not explicit. The programme documents, however, explicitly addressed all three APC dimensions. Two of the APC dimensions - socio-economic and socio-cultural - were well tailored into the concrete activities at the programme level and these competences were apparent also in learners' statements about their gains from the program.

\section{Discussion}

As a new direction, the Baltic states are considering sustainable and holistic approaches that highlight personal self-development besides their employability goals (LLL 2020, 2014). In Latvia and Lithuania the steps have been made at the level of national acts to move from the "adult education" to "education for adults" concept, which addresses also the persons' self-development in civil society as part of $\mathrm{AE}$ goals. However, in Estonia attention is given to the developments of jobrelated skills and entrepreneurship competencies as the goals for participation in adult education. The latest trends in adult education are the quality of educational providers, increasing the educational possibilities for adults, focusing on the continuing education courses from the labour market point of view, and promoting onthe-job training models.

The analysis of the two presented cases (see Table 8.1) suggests that in Latvian case the learners' group was more proactive, and despite of lacking formal education, young adults have demonstrated some entrepreneurship competences acquired through their experiences. In the Estonian case the target group consisted of young adults with lower cognitive abilities and weak aspirations. The young adults from the Latvian case had gained qualitatively more aspects of the socio-cultural dimension of APC from the programme compared with Estonian young adults whose learning experiences and skills associated more to self-regulation aspects.

Both the review of literature and the consideration of the two cases suggest that to be an active citizen one should be educated not only for the job and participation in labour market, but equipped with the conceptual knowledge, skills and values required to make informed of the decisions in one's life (Koke and Oganisjana 2005: 50). As we observed in our cases, this could happen in learning through active participatory citizenship if APC became embedded into the formats of providing adult education (Kalekin-Fishman et al. 2007; EduMAP Concept Note 2017). In 
Table 8.1 Comparison of two AE approaches practiced in Latvia and Estonia

\begin{tabular}{|c|c|c|c|}
\hline $\begin{array}{l}\text { Active } \\
\text { Participatory } \\
\text { Citizenship } \\
\text { dimensions } \\
\end{array}$ & $\begin{array}{l}\text { Legislative documents and } \\
\text { policy-makers }\end{array}$ & $\begin{array}{l}\text { Adult education } \\
\text { institutions and adult } \\
\text { educators }\end{array}$ & Young adults \\
\hline Estonia & $\begin{array}{l}\text { Adult education for } \\
\text { vocation and } \\
\text { entrepreneurship. Policy } \\
\text { documents and interviews } \\
\text { with policy-makers } \\
\text { revealed mostly the } \\
\text { socio-economic dimension } \\
\text { of APC. Educational goals } \\
\text { for young adults were not } \\
\text { holistically oriented. }\end{array}$ & $\begin{array}{l}\text { Promoting on-the-job } \\
\text { training models. } \\
\text { Continuing education } \\
\text { courses from the } \\
\text { labour market point of } \\
\text { view. } \\
\text { Adult educators } \\
\text { recognized supporting } \\
\text { particularly the } \\
\text { socio-cultural aspects, } \\
\text { but these were not well } \\
\text { embedded to the } \\
\text { programme. }\end{array}$ & $\begin{array}{l}\text { Were with weak } \\
\text { aspirations and cognitive } \\
\text { abilities- they received } \\
\text { learning experiences and } \\
\text { skills associated more to } \\
\text { self-regulation aspects. } \\
\text { Were not knowing well } \\
\text { their rights and } \\
\text { opportunities. }\end{array}$ \\
\hline Latvia & $\begin{array}{l}\text { At the policy documents } \\
\text { and among the } \\
\text { policymakers the APC } \\
\text { concepts were not explicit. } \\
\text { Moving towards the } \\
\text { "education for adults" } \\
\text { concept addressing also the } \\
\text { persons' self-development } \\
\text { in civil society. }\end{array}$ & $\begin{array}{l}\text { Accrediting informally } \\
\text { obtained domain } \\
\text { related competences } \\
\text { but not general } \\
\text { competences. } \\
\text { Two of the APC } \\
\text { dimensions - Socio- } \\
\text { economic and } \\
\text { socio-cultural were } \\
\text { well tailored to the } \\
\text { concrete activities at } \\
\text { the programme level. } \\
\text { Some learning } \\
\text { outcomes of politico- } \\
\text { legal dimension were } \\
\text { embedded into the } \\
\text { programme. }\end{array}$ & $\begin{array}{l}\text { Were more proactive } \\
\text { despite of lacking formal } \\
\text { education and had } \\
\text { developed } \\
\text { entrepreneurship } \\
\text { competences through } \\
\text { their experiences. } \\
\text { Admitted the need to } \\
\text { develop responsibility, } \\
\text { self-organization, } \\
\text { aspirations and aims. } \\
\text { Became more active as } \\
\text { responsible citizens } \\
\text { participating in voting, } \\
\text { and being active in work } \\
\text { unions. }\end{array}$ \\
\hline
\end{tabular}

both cases the programmes did not specifically highlight the concept of active participatory citizenship, and learning for all dimensions of active citizenship was not explicitly demonstrated. Analyzing stakeholders and the programme documents asserted that the socio-economic dimension of active citizenship manifested itself as the most prominent element of the programme. Young adults expressed also the need to gain more competences in politico-legal domain of APC. We may also assure that holistic approach in three inseparable aspects of qualification, socialization and subjectification (Biesta 2015) and the transformative effect of learning (Yang 2003, 2006) could be observed in young adults' experiences in both cases. Their understanding of active citizenship and expectations in relation to adult education programmes coincided with the aspects highlighted by young adults reported by Lister et al. (2003). The two observed cases blended different forms of learning, from which workplace learning seemed to have had some impact on learners' 
socio-economic and some socio-cultural competencies. However, adult educators of the observed programmes were particularly addressing the need to find ways on how to develop socio-cultural competences of the young adults from risk groups. Particularly the subjectification aspects such as responsibility, self-organization, aspirations and aims (Biesta 2015) need to be supported among them. Both programmes were targeting all types and ages of learners and did not have a specific focus on young adults from vulnerable groups, therefore, there was a lack of specific elements that could support such learners. This was particularly evident in the Estonian case of workplace learning. In the Latvian case, we would particularly address the issue that even though this programme is developing and accrediting domain related competences, it fails to develop and evaluate general competences the young adults have acquired from previous experiences.

\section{Conclusion}

To conclude, the observed cases in all three Baltic States have already demonstrated the intention to move beyond the neoliberal education model, while applying holistic forms of adult education. The informal learning approaches used in the Baltic States are fit for holistic education goals, but there is a way to go in terms of how to broaden assumptions and operationalise learning for the socio-cultural and also the politico-legal dimensions of active participatory citizenship. Learning for socialization and learning for subjectification are not targeted at action levels in observed programmes for adult learning. The holistic approach needs to be strengthened both as a goal of learning for active citizenship that should be directly embedded into policies and adult education programmes. In addition, it should be put in action as learning through active citizenship at workplace learning situations where the sociocultural and politico-legal dimensions of APC might also be practiced.

\section{References}

Aava, K. (2009). Haridusalaste tekstide võrdlev diskursusanalüüs (comparative discourse analysis of educational texts). Eesti rakenduslingvistika Ühingu Aastaraamat (Estonian Papers in Applied Linguistics), 5, 7-17.

Adults participation in learning. EUROSTAT 2019. URL: https://ec.europa.eu/eurostat/tgm/ refreshTableAction.do?tab=table\&plugin=1\&pcode=sdg_04_60\&language=en. Accessed 29.05.2019.

Aspin, D., Chapman, J., Hatton, M., \& Sawano, Y. (eds.) (2012). The handbook of lifelong learning. Dordrecht: Springer.

Biesta, G. (2015). What is education for? On good education, teacher judgment, and educational professionalism. European Journal of Education, 50(1), 75-87.

Brooks, R. M., \& Holford, J. A. K. (2009). Citizenship, learning and education: Themes and issues. Citizenship Studies, 13(2), 85-103. 
Commission of the European Communities. (2000). http://arhiv.acs.si/dokumenti/Memorandum_ on_Lifelong_Learning.pdf

Country Report on Adult Education in Estonia. (2011). Helsingi. EAEA. https://eaea.org/country/ estonia/. Accessed on 29.05.2019.

Dromantiene, L., \& Žemaitaitytè, I. (2014). Challenges of adult education in Lithuania. ProcediaSocial and Behavioural Sciences, 116, 4532-4536.

EC. (2016). An in-depth analysis of adult learning policies and their effectiveness in Europe. European Commission. Directorate General for Employment, Social Affairs and Inclusion, p. 154. https://ec.europa.eu/epale/sites/epale/files/all_in-depth_analysis_of_adult_learning_ policies_and_their_effectiveness_in_europe_12.11.2015_pdf.pdf

EC (2018). Education and Training MONITOR 2018 Latvia.

EduMAP Concept Note (2017) Adult Education as a Means to Active Participatory Citizenship: A Concept Note. Deliverables and reports. EduMAP project, Tampere University. https://projects.tuni.fi/uploads/2019/05/8ccf882f-edumap_concept-note.pdf. Accessed 15 March 2021.

Ernst \& Young. (2017). Eesti kõrgkoolide 2015. aasta vilistlaste uuring. https://www.hm.ee/sites/ default/files/uuringud/vil2015_aruanne.pdf

Estonian Human Development Report 2000. (2001). Tallinn: United Nations Programme.

Estonian Lifelong Learning Strategy. (2020). Estonian Ministry of Education and Research.

ET. (2020). National Report for Estonia. URL: http://ec.europa.eu/assets/eac/education/policy/ strategic-framework/doc/et2020-national-report-et_en.pdf. Accessed on 28.05.2019.

Helemäe, J., Saar, E., \& Vöörmann, R. (2000). Was it worthwhile to invest in education (pp. 143-187). Tallinn, Estonia: Estonian Academy of Sciences Press.

Holford, J., Ridell, S., Weedon, E., Litjens, J., Hannan, G., Mohorcic Sploar, V. A., Beltram, P., Ivancic, A., Miraceva, J. (2007). Lifelong learning patterns of policy in thirteen European countries LLL2010 SP 1 comparative report, LLL2010 project reports, 1.

Jarvis, P., \& Parker, S. (2005). Human learning: A holistic approach. In Routledge. London.

Jõgi, L. (2005). Adult education in Estonia. In L. Jõgi, E. Przybylska, \& M. Teresneviciene (Eds.), Adult learning for civil society. International perspectives in adult education (pp. 119-129). Bonn: IIZ/DVV.

Jõgi, L., \& Gross, M. (2009). The professionalisation of adult educators in the Baltic States. European Journal of Education, 44(2), 221-242.

Jõgi, L., \& Märja, T. (2000). Estonia in the Grip of Change: The role of education for adults in the transition period. In Globalisation, educational transformation and societies in transition. Symposium books, pp. 99-105.

Jõgi, L., Karu, K., Krabi, K. (2007). Underdstanding Lifelong learning in Estonia - Voices from experts, decisionmakers and adult learners. In E. Lucio-Villegas \& M. del Carmen Martinz (Eds.), Proceedings of the 5Th ESERA research conference "Adult learning and the challenges of social and cultural diversity: Diverse lives, cultures, learnings and literacies (pp. 119-134). Sevilla: University of Sevilla.

Kalekin-Fishman, D., Tsitselikis, K., \& Pitkänen, P. (2007). Theorizing multiple citizenship. In D. Kalekin-Fishman \& P. Pitkänen (Eds.), Multiple citizenship as a challenge to European nation-states (pp. 1-38). Rotterdam: Sense Publishers.

Kārklina, S., \& Papule, E. (2017). Adult learning in Latvia. In Proceedings of the LR Ministry of Education and Science International scientific conference "Challenges for High Quality of Adult Education" (pp. 97-110). Riga: Ministry of Education and Science of the Republic of Latvia.

Koḳe, T. (1999). Pieaugušo mācī̌sanās sociāli pedagoǵiskie pamati: habilitācijas darbu un kopsavilkuтu kopa / Tatjana Koḳe (p. 1999). Rīga: LU.

Kārkḷina, S., Kraže, S., Šenberga, A., \& Volkova T. (2017). Quality issues of non-formal and formal adult education. In Proceedings of the LR Ministry of Education and Science International scientific conference "Challenges for High Quality of Adult Education" (pp. 85-96). Riga: Ministry of Education and Science of the Republic of Latvia. 
Kera, S. (1996). Education in Estonia: Historical overview up to 1991. Tallinn: Estonian Ministry of Education.

Koke, T., \& Oganisjana, K. (2005). Educational experience as a path to active citizenship. In L. Jõgi, E. Przbulska, \& M. Teresneviciene (Eds.), Adult learning for civil society (pp. 39-53). Bonn: IIZ7DVV.

Lifelong Learning Needs Analysis/Elukestva Õppe Vajaduste Analüüs. Uuringu Aruanne (2001). Tallinn, Saar-Poll Sotsiaal- ja Turu-uuringud, ETKA "Andras".

Lister, R., Smith, N., Middleton, S., \& Cox, L. (2003). Young people talk about citizenship: Empirical perspectives on theoretical and political debates. Citizenship Studies, 7(2), 235-253.

MoER. (2015). Ministry of Education and Research, 'Adult skills: Their use and usefulness in Estonia'. Summaries of thematic reports on the PIAAC study.

Roosalu, T., \& Roosmaa, E.-L. (2010). Back at school: Do they really have nothing else to do? Lifelong learning ideologies. In V. Kozlovkiy, R. Vöörmann, \& T. Roosalu (Eds.), Learning in transition: Policies and practices of lifelong learning in post-soviet countries (pp. 41-65). St. Peterburg, Nauka.

Ross, L. W. (1960). Some aspects of Soviet education. The Journal of Teacher Education, XI(4), 539-552.

Saar, E., Roosalu, T., Roosmaa, E.-L., Tamm, A., \& Vöörmann, R. (2013). Developing human capital in post-socialist capitalism: Estonian experiences. In E. Saar, O. B. Ure, \& J. Holford (Eds.), Lifelong learning in Europe National Patterns and challenges (pp. 372-396). Cheltenham: Edward Elgar Publishing.

Špona, A. (2018). Jauns pedagogijas zinātnes priekšmets. Latvijas Zinātnes Akadēmijas vēstnesis, 15-22.

Taljūnaitè, M. Dromantienè, L. Žemaitaitytė I., \& Labanauskas L. (2010). Adult education in Lithuania: Towards increasing employability and social cohesion, or neither?

Yang, B. (2003). Toward a holistic theory of knowledge and adult learning. Human Resources Development Review, 2(2), 106-129.

Yang, B. (2006). A holistic conceptualization of adult learning and its critiques of selected concepts and theories. In Adult education research conference. http://newprairiepress.org/ aerc/2006/papers/79

Open Access This chapter is licensed under the terms of the Creative Commons Attribution 4.0 International License (http://creativecommons.org/licenses/by/4.0/), which permits use, sharing, adaptation, distribution and reproduction in any medium or format, as long as you give appropriate credit to the original author(s) and the source, provide a link to the Creative Commons licence and indicate if changes were made.

The images or other third party material in this chapter are included in the chapter's Creative Commons licence, unless indicated otherwise in a credit line to the material. If material is not included in the chapter's Creative Commons licence and your intended use is not permitted by statutory regulation or exceeds the permitted use, you will need to obtain permission directly from the copyright holder.

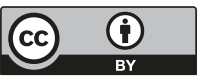

